\title{
“紫砂本不语, 科学自有声”一一科学解读宜兴紫砂壸
}

\author{
千人计划专家联谊会青年千人专家委员会, 宜兴市陶瓷行业协会
}

“开门七件事, 柴米油盐酱醋茶”. 在中国茶文化中, 沏出浓香纯厚的好茶, 不仅需要精选的茶叶, 还需要使用 讲究的茶具. 紫砂壸则是公认的冲泡茶水最好的容器, 而 制作紫砂壸最好的地方为江苏宜兴. 墨客骚人在用典雅的 紫砂壸泡茶品饮时, 是“几案有一具, 生人闲远之思”, 已 然超越饮茶本身. 既然在文人雅客眼中的紫砂古朴纯厚, 不媚不俗, 在科技如此发达的当下, 我们何不借以各类先 进的仪器再从科学角度一探紫砂壸的独特之处呢?

2016 年 5 月千人计划专家联谊会青年千人专家委员 会联合宜兴市陶瓷行业协会, 对宜兴紫砂壸做出了科学细 致的定量研究. 几位青年千人专家代表, 重庆大学刘雾宇 教授、中国科学院物理研究所金鬼研究员、北京航空航天 大学杨树斌教授和中国科学院微生物研究所傅钰研究员 课题组分别进行了微观形貌表征, 并对热扩散系数、元素 浸出、抑菌性做了测量, 通过定量化参数来科学解读紫砂
垩提携不惣手、泡茶不走味、咜茶不变色、盛暑不易舅的 真正原因.

研究人员用扫描电子显微镜(简称扫描电镜或 SEM) 对所收集的三种紫砂陶片(图 1)微观形貌进行了表征. 在 扫描电镜下, 三种样品均呈现多孔结构, 这种独特的结构 使得紫砂器具有良好的透气性, 从而使紫砂壸沏茶不失原 味, 且香气四溢而不涣散, 得茶之真味真香. 通过德国 Linseis LFA1000 激光导热仪测量样品的热扩散系数, 发现 随着温度的增加, 所有样品的热扩散系数却是逐渐降低, 因此紫砂壸在注人沸水时不会炸裂，注人沸水后提携抚拿 而不惣手.

研究人员还利用电感耦合等离子光谱发生仪(Inductive Coupled Plasma Emission Spectrometer)测量了紫砂茶杯浸泡 过的超纯水中矿物元素含量(图 1(d), (e)所示). 与玻璃试剂瓶 相比, 紫砂茶杯浸泡后有钙 $(\mathrm{Ca}) 、$ 钾 $(\mathrm{K})$ 、镁 $(\mathrm{Mg})$ 、钠 $(\mathrm{Na})$ 、

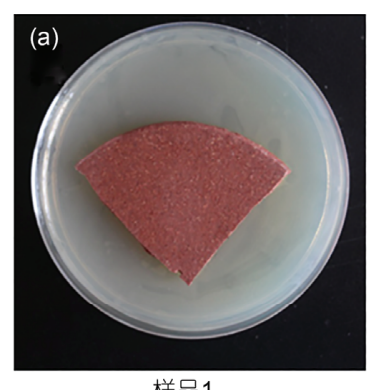

样品1

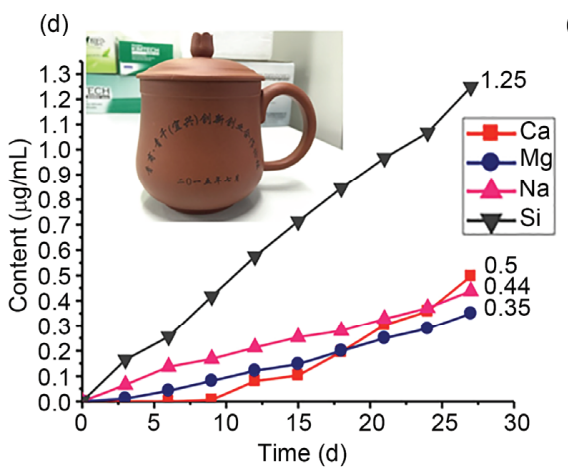

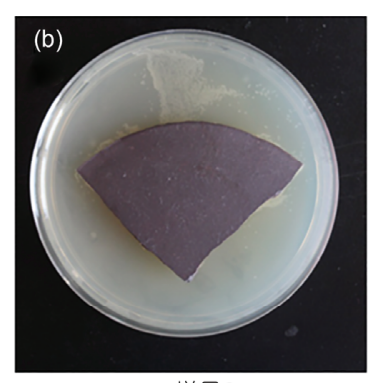

样品2

(e)

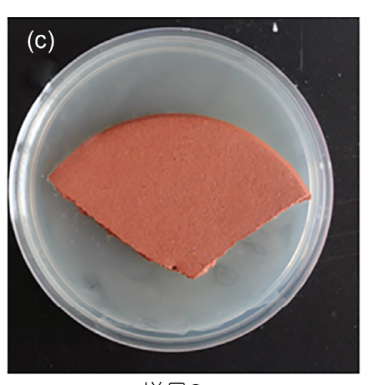

样品3

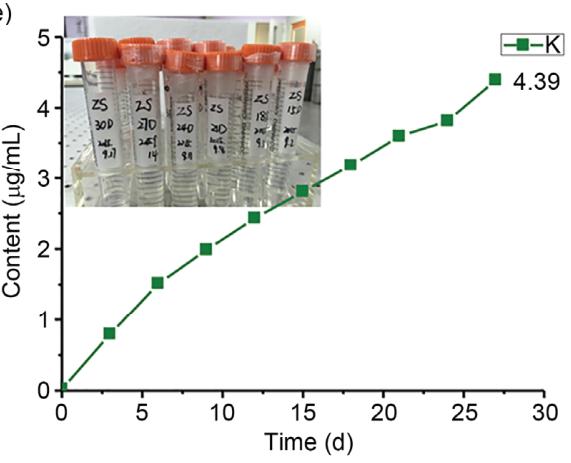

图 1 (a) (c) 3 种样品分别为不同紫砂陶原料制成的前体; (d) 钠、镁、钙、硅含量的时间变化曲线, 左上小图为实验所用紫砂茶杯; (e) 钾元素含量的时间变化曲线, 左上小图为实验样本. 实验所测试的紫砂陶片样品

Figure 1 Zisha pottery samples (a)-(c) Three kinds of Zisha pottery made by different clay; (d) Plot of the distribution of $\mathrm{Na}$, Mg, Ca and Si depending on Soaking time, the upper inset shows the teapot used in the experiment; (e) Plot of the distribution of K depending on soaking time, the upper inset shows the samples. 
硅 $(\mathrm{Si}) 5$ 种矿物元素浸出, 与市面上销售的矿泉水成分类似, 可见紫砂壸可以一定程度上改变水质, 提升水中矿物质含 量. 众所周知, 紫砂制品主要成分赤铁矿中铁、锰含量较 高, 但是在试验中没有发现铁锰离子的浸出, 这可能因为 铁、锰化合物在常温常压条件下很稳定, 难以通过浸泡的 方式以离子形式游离. 同时实验发现即使是经过了 27 天 的浸泡, 也未在紫砂制品所盛的水中检测出对人体健康有 害的重金属元素, 如镉 $(\mathrm{Cd})$ 、采 $(\mathrm{Hg})$ 、银 $(\mathrm{Ag})$ 、铜 $(\mathrm{Cu})$ 、钡 $(\mathrm{Ba})$ 、铅 $(\mathrm{Pb})$ 等. 这表明用紫砂制品泡茶, 并不会因紫砂本 身产生重金属污染.

对于紫砂壸的抑菌性, 研究人员也做了一些探讨. 实 验结果显示紫砂陶片对水的酸碱性改变不大, 因此不能通 过大幅改变水的酸碱性来抑制某些细菌的生长. 采用大肠 杆菌(DH5o)菌株, 浸泡过紫砂陶的蒸馏水(浸泡 $24 \mathrm{~h}$ )及紫 砂陶片本身都没有形成抑菌圈, 这些实验结果暗示紫砂壸 沏茶后茶水不馊可能并不是由于紫砂本身含有杀菌或者
抑菌的物质, 而是得益于紫砂売特殊的材质和自身结构. 扫描电镜的结果证明紫砂为多孔性材质, 气孔细微并且密 度高, 因此具有很好的透气性, 此种结构有助于保证噎水 中的氧分子浓度维持在一个较高的范围, 不利于厌氧微生 物的活动. 另外，紫砂壸口盖设计精巧，壸盖与口之间“缝 无纸发之隙”; 紫砂壸通常嘴小, 且壸嘴流出口成一定斜角, 大大降低了空气中微生物进人壸中的机会, 加之倒人壹中 的水为杀死微生物的沸水, 因此微生物在壸内发酵的机会 大大降低，所以成就了紫砂壸泡香芳“盛暑越宿不馊”、“不 夺茶味”的美誉.

此次研究通过科学测量来解读紫砂, 揭示了紫砂壹众 多优良特性的科学缘由，也打破了之前公众及媒体宣传中 对紫砂制品的多种误解. 紫砂壸不仅代表了一种文化, 其 完美的结构设计巧妙合理又增添壸型之美, 高精度的制作 工艺体现了制陶者的智慧, 也展示了深刻的科学性, 可谓 巧夺天工.

\section{推荐阅读文献}

1 Zi T. Zisha in China (in Chinese). Beijing: Current Affairs Press, 2014 [紫檀. 中国紫砂. 北京: 时事出版社, 2014]

2 Lin X L. Yixing Zisha in literature (in Chinese). Jiangsu Ceram, 2012, 45: 22 [林小龙. 文学中的宜兴紫砂壸探微. 江苏陶瓷, 2012, 45: 22]

3 Zhou Q D. Preliminary study of the characteristics and cultural implication of Zisha teapot (in Chinese). China Ceram Ind, 2008, 15: 46-47 [周琴娣. 浅谈紫砂壸艺的特点及其文化内涵. 中国陶瓷工业, 2008, 15: 46-47]

4 Ma Z Y. The characteristics of Yixing Zisha: materials, technology, function and artistic value (in Chinese). Ceram Sci Art, 2008, 15: 46-47 [马志远. 也论紫砂陶的特性：基于原料、工艺、功能和艺术价值. 陶瓷科学与艺术, 2008, 15: 46-47]

5 Jiang A S. Study on Zisha (in Chinese). China Ceram, 1992, 126: 47-48 [蒋敖生. 试论紫砂. 中国陶瓷, 1992, 126: 47-48]

6 Jiang X, Wu J, Zhang M L, et al. The characteristics of Yixing Zisha clay (in Chinese). Jiangsu Ceram, 2011, 44: 20-25 [江夏, 吴隽, 张 茂林, 等. 宜兴紫砂泥性能研究. 江苏陶瓷, 2011, 44: 20-25]

7 Zhao J. Treatise on Tea (in Chinese). Beijing: Zhonghua Book Company, 2013 [赵佶. 中华生活经典: 大观茶论. 北京: 中华书局, 2013]

8 Ye X Y. The study of distribution of trace element in water (in Chinese). J Southw Univ Natl, 1988, 3: 65-73 [叶希尧. 水中部分微量元 素分布规律的研究. 西南民族学院学报, 1988, 3: 65-73]

9 Han R J, Ye L G, He P F, et al. Technological features and microstructure of Yixing teapot (in Chinese). Silicate, 1981, 4: 26-35 [韩人杰, 叶龙耕, 贺盘发, 等. 宜兴紫砂陶的生产工艺特点和显微结构. 硅酸盐, 1981, 4: 26-35] 


\title{
Decipher the science in Yixing purple-clay
}

\author{
Young Professionals Committee, Association of Thousand Talents Program, Yixing Ceramic Association
}

The long standing and well established Chinese tea culture creates intricate aesthetics on both substantial and spiritual aspects, where tea sets definitely serve as an important carrier. Purple-clay teapot from Yixing is recognized as one of the best of tea sets. What are the unique characteristics and the underlying science of the highly praised Yixing purple-clay? Taking the advantage of advanced technologies, we investigated purple-clay teapots from the scientific perspective, including the micro-morphology, thermal diffusivity, trace elements, bacterial inhibition, etc. As discovered by experiments, the special micro-porous structures of purple-clay teapots ensure the excellent air permeability; the typical thermal property enables the temperature preservation of tea; the characteristic materials of purple-clay enrich trace elements in water, leading to improvement of the quality of water to some extent; in addition, the distinctive design of purple-clay teapot effectively depress the entrance of micro species, resulting in the highly reduced fermentation of microorganisms. The immaculate design and the unique composition of Yixing purple-clay teapots not only enable them to benefit the taste and healthiness of tea, but also endow them infinite art enchantments.

purple-clay teapots, thermal diffusivity, trace elements, bacterial inhibition

doi: 10.1360/N972016-00595 